\title{
Arbeidsmarktprognoses Rijk van Nijmegen 2017-2022
}

Citation for published version (APA):

Peeters, T., \& Cörvers, F. (2018). Arbeidsmarktprognoses Rijk van Nijmegen 2017-2022. ROA. ROA Fact Sheets No. 010D https://doi.org/10.26481/umarof.2018010D

Document status and date:

Published: 01/01/2018

DOI:

10.26481/umarof.2018010D

Document Version:

Publisher's PDF, also known as Version of record

\section{Please check the document version of this publication:}

- A submitted manuscript is the version of the article upon submission and before peer-review. There can be important differences between the submitted version and the official published version of record.

People interested in the research are advised to contact the author for the final version of the publication, or visit the DOI to the publisher's website.

- The final author version and the galley proof are versions of the publication after peer review.

- The final published version features the final layout of the paper including the volume, issue and page numbers.

Link to publication

\footnotetext{
General rights rights.

- You may freely distribute the URL identifying the publication in the public portal. please follow below link for the End User Agreement:

www.umlib.nl/taverne-license

Take down policy

If you believe that this document breaches copyright please contact us at:

repository@maastrichtuniversity.nl

providing details and we will investigate your claim.
}

Copyright and moral rights for the publications made accessible in the public portal are retained by the authors and/or other copyright owners and it is a condition of accessing publications that users recognise and abide by the legal requirements associated with these

- Users may download and print one copy of any publication from the public portal for the purpose of private study or research.

- You may not further distribute the material or use it for any profit-making activity or commercial gain

If the publication is distributed under the terms of Article $25 \mathrm{fa}$ of the Dutch Copyright Act, indicated by the "Taverne" license above, 


\section{Maastricht University $\$$ ROA}

\section{Arbeidsmarktprognoses}

Rijk van Nijmegen 2017-2022

Tim Peeters

Frank Cörvers

\section{ROA Fact Sheet}

ROA-F-2018/10D

Researchcentrum voor Onderwijs en Arbeidsmarkt | ROA Research Centre For Education and the Labour Market / ROA 


\section{Arbeidsmarktprognoses Rijk van Nijmegen 2017-2022}

Inleiding

Als onderdeel van het Project Onderwijs-Arbeidsmarkt (POA) stelt het ROA sinds 2013 tweejaarlijkse regionale arbeidsmarktprognoses op die tegemoet komen aan de toenemende belangstelling voor regionale arbeidsmarktinformatie. Binnen dit kader past ook voorliggende factsheet met arbeidsmarktprognoses voor het RijkvanNijmegen. Dezeprognosesbestrijkendeperiode20I72022 en worden weergegeven voor 24 opleidingscategorieën die verdeeld zijn over zes opleidingsniveaus. Waar mogelijk worden de prognoses vergeleken met deze voor Gelderland als geheel, en wordt er een relatie gelegd met zowel de sector- als opleidingsspecialisatie van de werkgelegenheid in de verschillende regio's. De interpretatie van de prognoses gebeurt steeds vanuit het perspectief van schoolverlaters en werkzoekenden.

De prognoses voor de hele provincie Gelderland evenals een leeswijzer kunnen gevonden worden in de factsheet met nummer ROA-F-2018/IO. Onderstaande kaart geeft aan hoe Gelderland is samengesteld uit de verschillende arbeidsmarktregio's, en de overzichtstabel laat de verschillende gemeenten zien die in het Rijk van Nijmegen gelegen zijn. Zie ten slotte Tekstbox I voor definities van de in deze factsheet gebruikte variabelen.

Arbeidsmarktregio's binnen Gelderland

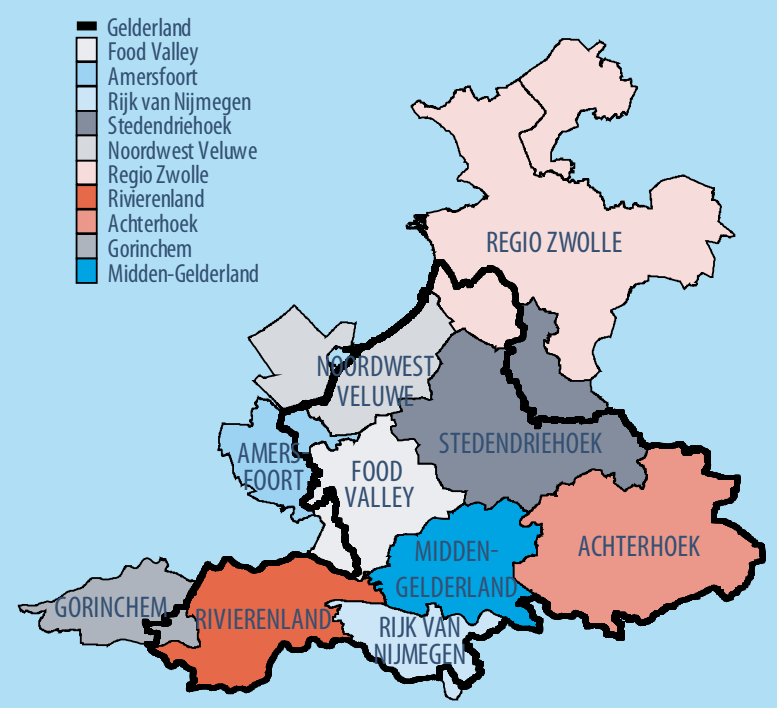

Gemeenten in het Rijk van Nijmegen

\begin{tabular}{l|l|}
\hline Gelderse gemeenten & Niet-Gelderse gemeenten \\
\hline Berg en Dal & Mook en Middelaar \\
\hline Beuningen & \\
\hline Druten & \\
\hline Heumen & \\
\hline Nijmegen & \\
\hline Wijchen & \\
\hline
\end{tabular}

\section{Prognoses en actuele arbeidsmarktcijfers naar} opleidingsniveau

De arbeidsmarktvooruitzichten voor het Rijk van Nijmegen zijn op geaggregeerd niveau met een ITA van I,O4 het minst gunstig van de zeven Gelderse regio's. Zoals blijkt uit Tabel I wijken de cijfers van deze arbeidsmarktregio bovendien op verschillende punten sterk af van de andere vijf arbeidsmarktregio's. In tegenstelling tot in de rest van Gelderland zijn de arbeidsmarktvooruitzichten voor hbo en wo hier namelijk gemiddeld zwakker dan voor mbo $2 / 3$ en mbo 4. Dit komt doordat een relatief grote instroom van hoger opgeleiden naar verwachting zal leiden tot een aanbodoverschot van zowel hbo als wo-schoolverlaters. Voor wo is dit in belangrijke mate een gevolg van de aanwezigheid van de Radboud Universiteit. Bovendien wordt voor wo een vervangingsvraag voorzien die slechts de helft bedraagt van deze van Gelderland als geheel.

Voor de opleidingsniveaus basisonderwijs/vmbo, mbo $2 / 3$ en mbo 4 wordt een beduidend hogere uitbreidingsvraag verwacht. Het aanzienlijke vraagoverschot dat wordt voorzien voor basisonderwijs en vmbo (ITA van 0,87 ) wordt daarenboven mede gedreven door een relatief grote verwachte jaarlijkse vervangingsvraag (4,I\% per jaar). Dit staat in contrast met havo/vwo, waar een zeer lage vervangingsvraag (gemiddeld I,I\% per jaar) zorgt voor een matig arbeidsmarktperspectief dat bovendien duidelijk minder gunstig is dan in de andere arbeidsmarktregio's.

Betreffende de actuele arbeidsmarktindicatoren vallen nog enkele zaken op. Zo zijn schoolverlaters van het hbo, basisonderwijs en vmbo in het Rijk van Nijmegen minder vaak werkzaam dan in Gelderland als geheel. De werkloosheid van schoolverlaters van het basisonderwijs en vmbo is tevens in geen enkele andere arbeidsmarktregio groter $(7 \%)$. Gediplomeerden van het hbo en wo werken ten slotte met respectievelijk $48 \%$ en $57 \%$ minder vaak voltijds dan in de provincie als geheel.

Het feit dat de ITA en dus het toekomstig arbeidsmarktperspectief voor basisonderwijs en vmbo $(0,87)$ gunstiger is dan voor hbo en wo (I,II), dient met enige voorzichtigheid geïnterpreteerd te worden. Een aanzienlijk deel van de vraag naar personen met basisonderwijs of vmbo als opleidingsachtergrond heeft namelijk betrekking op laagbetaalde en kleine banen. Dit kan afgeleid worden van het relatief lage uurloon (13,7 euro), het lage gemiddeld aantal gewerkte uren per week $(25,5)$ en het hoge aandeel van studenten en scholieren (24\%). Bovendien gaat het vaak om flexibele banen met weinig doorgroeimogelijkheden. Enerzijds blijkt dit uit het lage percentage dat voltijds en vast in dienst is. Anderzijds komt dit ook tot uiting in het slechte loopbaanperspectief. De variabele "typering loopbaan", die per opleidingsniveau de loongroei tussen ca. 25 en 45 jaar (berekend voor Nederland als geheel) weergeeft in 2016, 
is namelijk het minst gunstig voor laagopgeleiden, en het meest gunstig voor havo/vwo. ${ }^{\mathrm{I}}$ Deze laatste groep bestaat mogelijk deels uit mensen die geen hogere opleiding hebben afgemaakt omdat ze door hun persoonlijke capaciteiten uitstekende kansen op de arbeidsmarkt hadden.

Verder is van belang dat de groep van laagopgeleiden met basisonderwijs of vmbo heel heterogeen is: niet alleen scholieren, maar ook voortijdig schoolverlaters zonder startkwalificatie (minimaal mbo 2 of havo), schoolverlaters van het speciaal onderwijs en arbeidsgehandicapten. Bij het aangegeven goede arbeidsmarktperspectief is geen rekening gehouden met de mogelijke sociale, fysieke en cognitieve beperkingen van mensen binnen deze groep.

\section{Sectorspecialisatie}

Zoals blijkt uit Figuur I die de sectorspecialisatie ${ }^{2}$ in het Rijk van Nijmegen weergeeft, kent deze arbeidsmarktregio een zeer uitgesproken focus op de zorgsector. Daarmee verschilt ze sterk van de andere arbeidsmarktregio's, in het bijzonder van Food Valley. Eenzelfde focus op de welzijnssector is echter niet aanwezig. Daarnaast heeft het Rijk van Nijmegen een specialisatie in onder meer openbaar bestuur en overheidsdiensten, het onderwijs en de horeca. Voor deze laatste twee sectoren is dit een gevolg van de grote studentenpopulatie in Nijmegen. Het werkgelegenheidsaandeel van de meeste andere sectoren is kleiner dan dat van Gelderland als geheel. Dat is ook het geval voor de industriesectoren. Opvallend is ten slotte de beperkte relatieve aanwezigheid van de groot- en detailhandel.

\section{Arbeidsmarktperspectieven naar opleidingscategorie}

De prognoses naar opleidingsniveau uit de eerste paragraaf kunnen verder uitgesplitst worden naar opleidingscategorie. Dit is weergegeven in Figuur 2, die per opleidingscategorie binnen het lager en middelbaar (beroeps)onderwijs toont hoe de totale arbeidsvraag en het totale arbeidsaanbod zich naar verwachting de komende zes jaar in het Rijk van Nijmegen zullen verhouden. Figuur 3 doet hetzelfde voor het hoger onderwijs.

De kleuren bakenen de gebieden af die corresponderen met de vijf eerder besproken ITA-typeringen voor schoolverlaters, gaande van slecht $(\operatorname{rood}$ en ITA $>\mathrm{I}, \mathrm{I} 5)$ tot zeer goed (grijs en ITA $\leq 0,85$ ). Deze kunnen geïnterpreteerd worden als kwalitatieve aanduidingen van de verwachte

I De indicator voor loopbaanperspectief wordt berekend an de hand van het verschil in bruto uurloon van werkenden in de leeftijdsgroep 20-29 jaar en 40-49 jaar. Voor een argumentatie, zie Fouarge, D., Kriechel, B., \& Dohmen, T. (20I4), Occupational sorting of school graduates: The role of economic preferences, Journal of Economic Behavior \& Organization, 106, 335-351.

2 Gebaseerd op de werkzame beroepsbevolking uit de Enquête Beroepsbevolking (EBB), inclusief zelfstandigen. arbeidsmarktperspectieven. Voor de punten op de middelste diagonale lijn zijn verwachte vraag en aanbod aan elkaar gelijk, wat correspondeert met een ITA gelijk aan I. Bijvoorbeeld, voor hbo techniek bedragen het totale aanbod en de totale vraag over zes jaar respectievelijk (afgerond) $28 \%$ en $38 \%$. Deze waarden impliceren een ITA van 0,93 , zodat hbo techniek zich bevindt in het donkerblauwe gedeelte met het perspectief "goed". ${ }^{3}$ Merk op dat deze ITA een gemiddelde betreft van de opleidingscategorie hbo techniek, en dat er variatie kan bestaan in de arbeidsmarktperspectieven van de onderliggende opleidingstypes.

Net als Tabel I geven eveneens de vraag- en aanbodverhoudingen naar opleidingscategorie voor de komende zes jaar een ander beeld dan die van Gelderland als geheel. Zoals blijkt uit figuren 2 en 3 is dit in het bijzonder het geval voor de hogere opleidingen. Daar valt op dat de meeste opleidingscategorieën een ITA hebben die groter is dan I en waarvoor dus een aanbod verwacht wordt dat groter is dan de vraag. Wo techniek is de enige wo-categorie waarvoor een goed arbeidsmarktperspectief wordt verwacht. Voor vier andere wo-categorieën worden daarentegen slechte arbeidsmarktperspectieven voorzien, meer bepaald voor wo economie en recht, wo onderwijs, wo taal en cultuur en wo gedrag en maatschappij. Elk van deze vier opleidingscategorieën heeft binnen Gelderland bovendien uitsluitend in het Rijk van Nijmegen een slecht arbeidsmarktperspectief. Figuur 3 maakt duidelijk dat dit hoofdzakelijk het resultaat is van een beperkte arbeidsvraag. Bij de hbo-opleidingen worden de beste arbeidsmarktvooruitzichten verwacht voor schoolverlaters van hbo techniek. Slechte perspectieven worden daarentegen voorzien voor afgestudeerden van hbo economie en hbo taal en cultuur (wegens een groot aanbod).

De prognoses naar opleidingscategorie voor de mbo-opleidingen liggen wel min of meer in lijn met deze van de andere arbeidsmarktregio's. Voor schoolverlaters van mbo 4 techniek en mbo 4 groen worden goede arbeidsmarktperspectieven verwacht. Dat geldt niet voor mbo 4 zorg en welzijn, waarvoor slechte arbeidsmarktperspectieven voorzien worden vanwege een groot arbeidsaanbod. Omdat ook de vooruitzichten voor hbo gezondheidszorg en wo medisch slechts matig zijn, suggereert dit dat werkgevers in de voor het Rijk van Nijmegen belangrijke zorgsector wellicht weinig moeilijkheden zullen ondervinden om geschikt personeel voor haar vacatures te vinden. De gunstigste vooruitzichten gelden ten slotte voor schoolverlaters van het basisonderwijs en vmbo, hoewel dit genuanceerd dient te worden in het licht van hun slecht loopbaanperspectief en doorgaans minder gunstige arbeidsvoorwaarden (zie Tabel I).

3 De berekening van de ITA is niet louter een deling van aanbod en vraag, aangezien teller en noemer nog dienen vermeerderd te worden met Ioo. 
Relatie arbeidsmarktperspectieven en specialisatie naar opleiding

Figuur 4 toont de relatie tussen de verwachte arbeidsmarktperspectieven (ITA) voor de verschillende opleidingscategorieën over de periode 20I7-2022 en de mate waarin het Rijk van Nijmegen in deze opleiding "gespecialiseerd" is. Deze laatste variabele is gelijk aan de ratio van het aandeel werkzame personen met een bepaalde opleidingscategorie die in het Rijk van Nijmegen wonen ten opzichte van het aandeel van die opleidingscategorie in het Nederlandse totaal. Indien de specialisatiecoëfficiënt voor een opleidingscategorie groter is dan I,oo, betekent dit dus dat het Rijk van Nijmegen in verhouding tot Nederland een groter aandeel van mensen met deze opleiding kent. Bijvoorbeeld, de opleidingsspecialisatiecoëfficiënt van I,69 die hoort bij hbo gezondheidszorg impliceert dat het aandeel van deze opleidingscategorie in het Rijk van Nijmegen 69\% groter is dan het aandeel van deze opleidingscategorie in Nederland als geheel. Arbeidsmarkttekorten zijn ernstiger naarmate de specialisatiegraad van de werkgelegenheid voor de betreffende opleidingscategorieën in een regio groter is. Het verband tussen de ITA en de specialisatie per opleidingscategorie in het Rijk van Nijmegen verschilt sterk van dat van de rest van Gelderland. De meeste hogere opleidingen zijn in het Rijk van Nijmegen namelijk proportioneel meer vertegenwoordigd dan in Nederland, en degenen die relatief vaker voorkomen hebben bovendien meestal een ongunstig arbeidsmarktperspectief. Dit is in het bijzonder het geval voor de wo-opleidingscategorieën. De opleidingen die het grootste aandeel kennen ten opzichte van Nederland zijn wo medisch, wo gedrag en maatschappij en hbo gezondheidszorg.

Hiertegenover staat dat alle mbo-opleidingen ondervertegenwoordigd zijn in verhouding tot Nederland. Dit neemt niet weg dat die ondervertegenwoordiging voor de meeste opleidingscategorieën toch samengaat met ongunstige arbeidsmarktvooruitzichten. Opmerkelijk daarbij is dat in tegenstelling tot de hogere zorggerichte opleidingen en ondanks het belang van de zorgsector, mbo 2/3- en mbo 4 zorg en welzijn ondervertegenwoordigd zijn in het Rijk van Nijmegen. De categorieën met het kleinste aandeel in de werkzame beroepsbevolking ten opzichte van Nederland zijn mbo 4 techniek en mbo $2 / 3$ groen.

Tekstbox 1 Definities kernbegrippen

\begin{tabular}{|c|c|}
\hline Variabele & Definitie \\
\hline Uitbreidingsvraag & $\begin{array}{l}\text { Vraag naar nieuwe arbeidskrachten die ontstaat door de groei van de werkgelegenheid. Als er sprake is van een werkgelegenheidsdaling, is de uitbreidingsvraag } \\
\text { negatief. }\end{array}$ \\
\hline Vervangingsvraag & $\begin{array}{l}\text { Vervangingsvraag is de vraag naar nieuwe arbeidskrachten die ontstaat door bijvoorbeeld pensionering, (tijdelijke) uittreding vanwege zorgtaken, } \\
\text { arbeidsongeschiktheid, beroepsmobiliteit of doorstroom naar een andere opleiding. }\end{array}$ \\
\hline Arbeidsmarktuitstroom & De som van de vervangingsvraag en de negatieve uitbreidingsvraag. \\
\hline Arbeidsmarktinstroom & $\begin{array}{l}\text { De arbeidsmarktinstroom is het verwachte aanbod van nieuwe arbeidskrachten op de arbeidsmarkt. Deze is gebaseerd op de verwachte uitstroom van } \\
\text { schoolverlaters uit het initiële dag-, deeltijd-, niet-reguliere voltijdonderwijs en de beroepsgerichte volwasseneneducatie. Het weergegeven aanbod in de } \\
\text { figuren } 2 \text { en } 3 \text { is de instroom. Gecorrigeerd voor mobiliteitsstromen tussen arbeidsmarktregio's. }\end{array}$ \\
\hline Baanopeningen & $\begin{array}{l}\text { Baanopeningen zijn de totale vraag naar nieuwkomers op de arbeidsmarkt, zoals deze is bepaald door de werkgelegenheidsgroei (positieve uitbreidingsvraag) } \\
\text { en de vervangingsvraag. In de figuren } 2 \text { en } 3 \text { is dit de vraag naar arbeid. }\end{array}$ \\
\hline ITA & $\begin{array}{l}\text { Indicator Toekomstige Arbeidsmarktperspectief (ITA) van schoolverlaters en werkzoekenden. Deze indicator is gelijk aan een deling van het verwachte aanbod } \\
\text { door de verwachte vraag tot 2022. Naarmate de waarde van de ITA hoger ligt, is er sprake van een slechter arbeidsmarktperspectief. Een waarde tussen 1,01 en } \\
1,05 \text { duidt op een evenwichtssituatie. }\end{array}$ \\
\hline Typering ITA & $\begin{array}{l}\text { Een kwalitatieve beschrijving van de ITA. ITA } \leq 0,85 \text { wordt als "zeer goed" getypeerd, ITA }>0,85 \text { en } \leq 1,00 \text { als "goed", ITA }>1,00 \text { en } \leq 1,05 \text { als "redelijk", ITA }> \\
1,05 \text { en } \leq 1,15 \text { als "matig" en ITA }>1,15 \text { als "slecht". }\end{array}$ \\
\hline Typering loopbaan & $\begin{array}{l}\text { Het bruto uurloon van werkenden in de leeftijdsgroep 40-49 jaar ten opzichte van het bruto uurloon van werkenden in de leeftijdsgroep } 20-29 \text { jaar. Gemiddelde } \\
\text { cijfers voor Nederland in } 2016 \text {. }\end{array}$ \\
\hline Bruto uurloon & $\begin{array}{l}\text { Gemiddeld bruto uurloon van werknemers in euro's. Enquête Beroepsbevolking (EBB) gekoppeld aan het Sociaal Statistisch Bestand (SSB) van het jaar } 2016 . \\
\text { Gemiddelde cijfers voor Nederland in } 2016 .\end{array}$ \\
\hline Werkenden & Minimaal 1 uur werkzaam per week en in de leeftijd 15-74. Cijfers op basis van de Enquête Beroepsbevolking van het CBS. \\
\hline Werkzaamheid & Het percentage werkzaam is de werkzame beroepsbevolking als percentage van de potentiële beroepsbevolking (iedereen ouder dan 15 en jonger dan 75 jaar). \\
\hline Werkloosheid & $\begin{array}{l}\text { Percentage personen die geen betaald werk hebben, wel recent hebben gezocht en daarvoor direct beschikbaar zijn als percentage van de totale } \\
\text { beroepsbevolking (werkzaam en werkloos). }\end{array}$ \\
\hline Vast werk & Personen met een vast dienstverband. Percentage op basis van werknemers in de werkzame beroepsbevolking. \\
\hline Voltijds & Voltijdarbeid betreft personen die minstens 35 uur per week werkzaam zijn. Percentage op basis van de werkzame beroepsbevolking. \\
\hline Leeftijd & Gemiddelde leeftijd. \\
\hline Uren & Gemiddeld aantal uren werk per week. \\
\hline Student/scholier & Percentage van de werkenden met maatschappelijke positie student/scholier. \\
\hline Sectorspecialisatie & $\begin{array}{l}\text { De verhouding tussen het aandeel van het aantal werkenden in een sector in een bepaalde regio ten opzichte van het aandeel van die sector in Nederland. Een } \\
\text { sectorspecialisatiecoëfficiênt groter dan } 1 \text { impliceert dat het aandeel werkenden in de desbetreffende sector in de regio groter is dan in Nederland als geheel. }\end{array}$ \\
\hline Opleidingsspecialisatie & $\begin{array}{l}\text { De ratio van het aandeel personen met een bepaalde opleidingscategorie die wonen in een bepaalde regio ten opzichte van het aandeel van die } \\
\text { opleidingscategorie in het Nederlandse totaal. Indien de specialisatiecoëfficiënt voor een opleidingscategorie groter is dan 1, betekent dit dat de regio in } \\
\text { verhouding tot Nederland een groter aandeel van mensen met deze opleiding kent. }\end{array}$ \\
\hline
\end{tabular}


Tabel 1

Arbeidsmarktprognoses (2017-2022) en actuele arbeidsmarktcijfers (2015-2016) Rijk van Nijmegen (RVN) en Gelderland (GLD) naar opleidingsniveau*

\begin{tabular}{|c|c|c|c|c|c|c|c|}
\hline & bo/vmbo & havo/vwo & mbo $2 / 3$ & mbo 4 & hbo & wo & totaal \\
\hline \multicolumn{8}{|l|}{ Prognoses } \\
\hline Uitbreidingsvraag (\%) & 1,1 & 0,7 & 1,2 & 1,4 & 0,9 & 0,9 & 1,0 \\
\hline Vervangingsvraag (\%) & 4,1 & 1,1 & 2,8 & 2,5 & 2,3 & 1,6 & 2,5 \\
\hline Arbeidsmarktinstroom (\%) & 1,9 & 2,0 & 3,6 & 4,3 & 4,7 & 4,3 & 3,6 \\
\hline ITA (RVN) & 0,87 & 1,12 & 1,03 & 1,06 & 1,11 & 1,11 & 1,04 \\
\hline Typering ITA (RVN) & goed & matig & redelijk & matig & matig & matig & redelijk \\
\hline ITA (GLD) & 0,93 & 1,04 & 1,07 & 1,08 & 1,04 & 0,99 & 1,01 \\
\hline Typering ITA (GLD) & goed & redelijk & matig & matig & redelijk & goed & redelijk \\
\hline Typering loopbaan (NL) ${ }^{* *}$ & slecht & zeer goed & matig & redelijk & redelijk & goed & -- \\
\hline \multicolumn{8}{|l|}{ Actuele indicatoren } \\
\hline Bruto uurloon (NL) ${ }^{* *}$ & 13,7 & 17,3 & 17,7 & 19,2 & 25,1 & 34,7 & -- \\
\hline Werkenden & 24.500 & 17.500 & 22.000 & 20.000 & 37.000 & 30.500 & 153.000 \\
\hline Werkzaamheid (\%) & 43 & 64 & 63 & 79 & 71 & 84 & 65 \\
\hline Werkloosheid (\%) & 7 & 5 & 5 & 5 & 4 & 4 & 5 \\
\hline Vast werk (\%) & 70 & 53 & 87 & 82 & 84 & 91 & 80 \\
\hline Voltijds (\%) & 40 & 29 & 50 & 46 & 48 & 57 & 46 \\
\hline Uren & 26,0 & 22,9 & 32,2 & 30,3 & 31,2 & 34,4 & 30,1 \\
\hline Leeftijd & 38,6 & 32,6 & 44,0 & 39,4 & 40,7 & 40,6 & 39,7 \\
\hline Student/scholier (\%) & 24 & 49 & 3 & 7 & 9 & 1 & 13 \\
\hline
\end{tabular}

"Prognoses als gemiddeld jaarlijks percentage van de werkzame beroepsbevolking in 2016; actuele indicatoren als percentage van de werkzame, totale of potentiële beroepsbevolking 2015-2016 (zie Tekstbox 1), tenzij anders aangegeven

** Lonen voor Nederland in 2016

\section{Figuur 1}

Actuele sectorspecialisatie Rijk van Nijmegen ten opzichte van Nederland en Gelderland (2015-2016) Voedings- en genotmiddelenindustrie Chemische industrie Metaalindustrie Overige industrie Energie Bouwnijverheid

Detailhandel

Groothandel

Vervoer en opslag Horeca

Informatie en communicatie Financiële dienstverlening en onroerend goed Special istische zakelijke dienstverlening Verhuur en overige zakelijke dienstverlening

Openbaar bestuur en overheidsdiensten Onderwijs Zorg Cultuur sport en recreatie Overige dienstverlening huishoudens en extraterritoriale organisaties

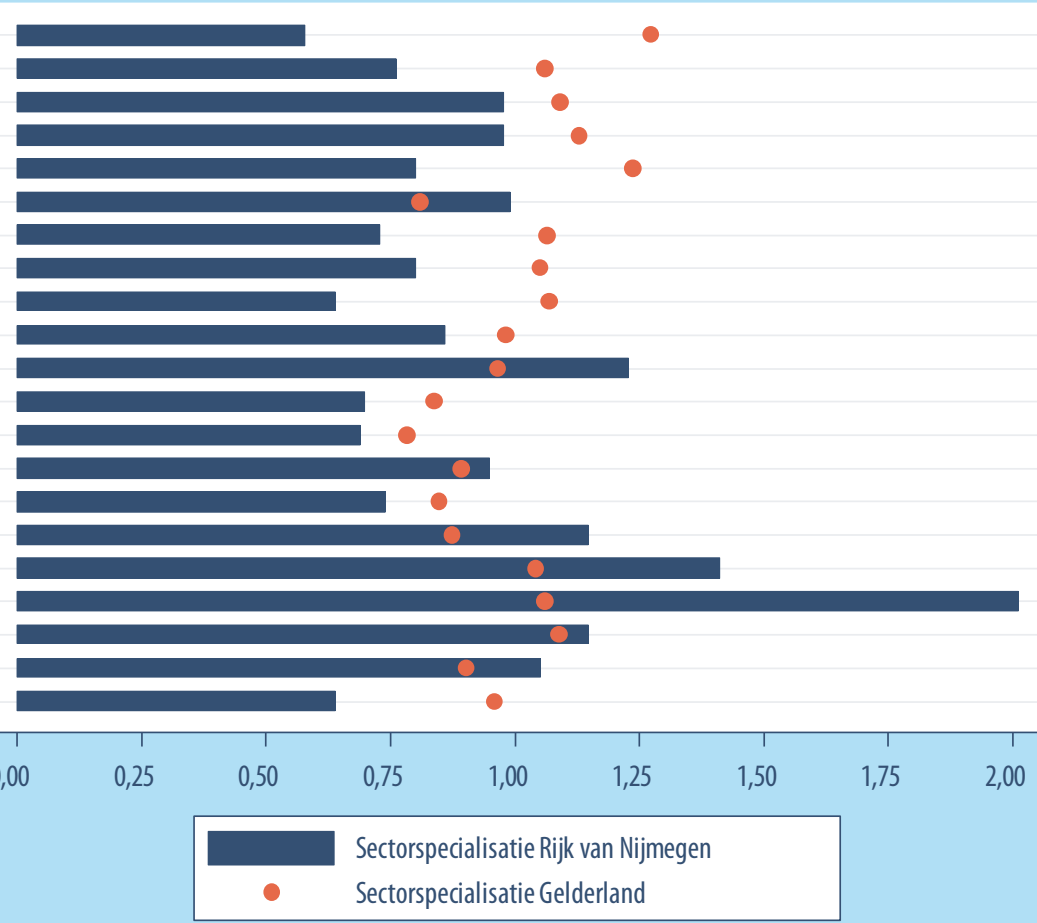


6 Arbeidsmarktprognoses Rijk van Nijmegen 2017-2022

\section{Figuur 2}

Vraag en aanbod voor opleidingscategorieën lager/middelbaar (beroeps)onderwijs, Rijk van Nijmegen (2017-2022)

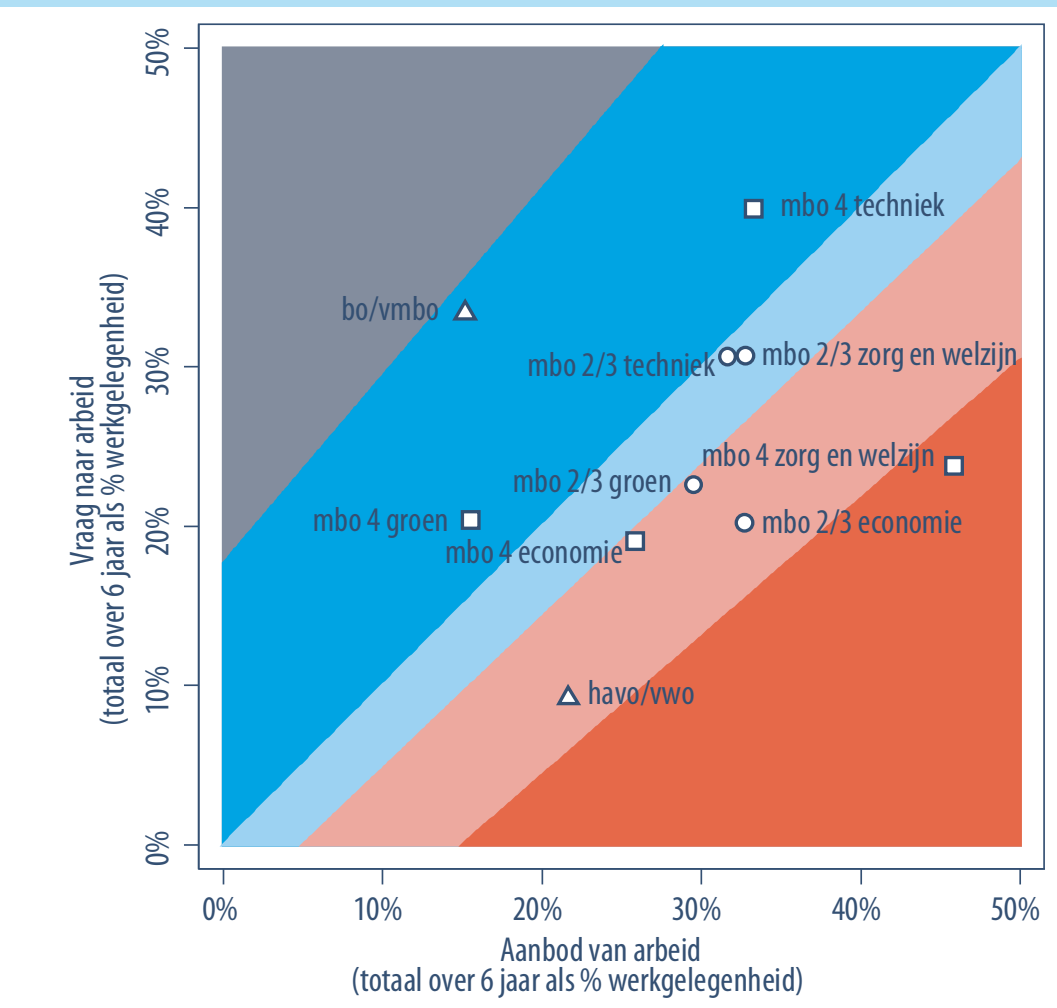

\begin{tabular}{|c|c|}
\hline & Perspectief zeer goed \\
\hline & Perspectief goed \\
\hline & Perspectief redelijk \\
\hline & Perspectief matig \\
\hline & Perspectief slecht \\
\hline$\Delta$ & bo/vmbo en ha \\
\hline 0 & mbo $2 / 3$ \\
\hline & mbo 4 \\
\hline
\end{tabular}

Figuur 3

Vraag en aanbod voor opleidingscategorieën hoger onderwijs, Rijk van Nijmegen (2017-2022)

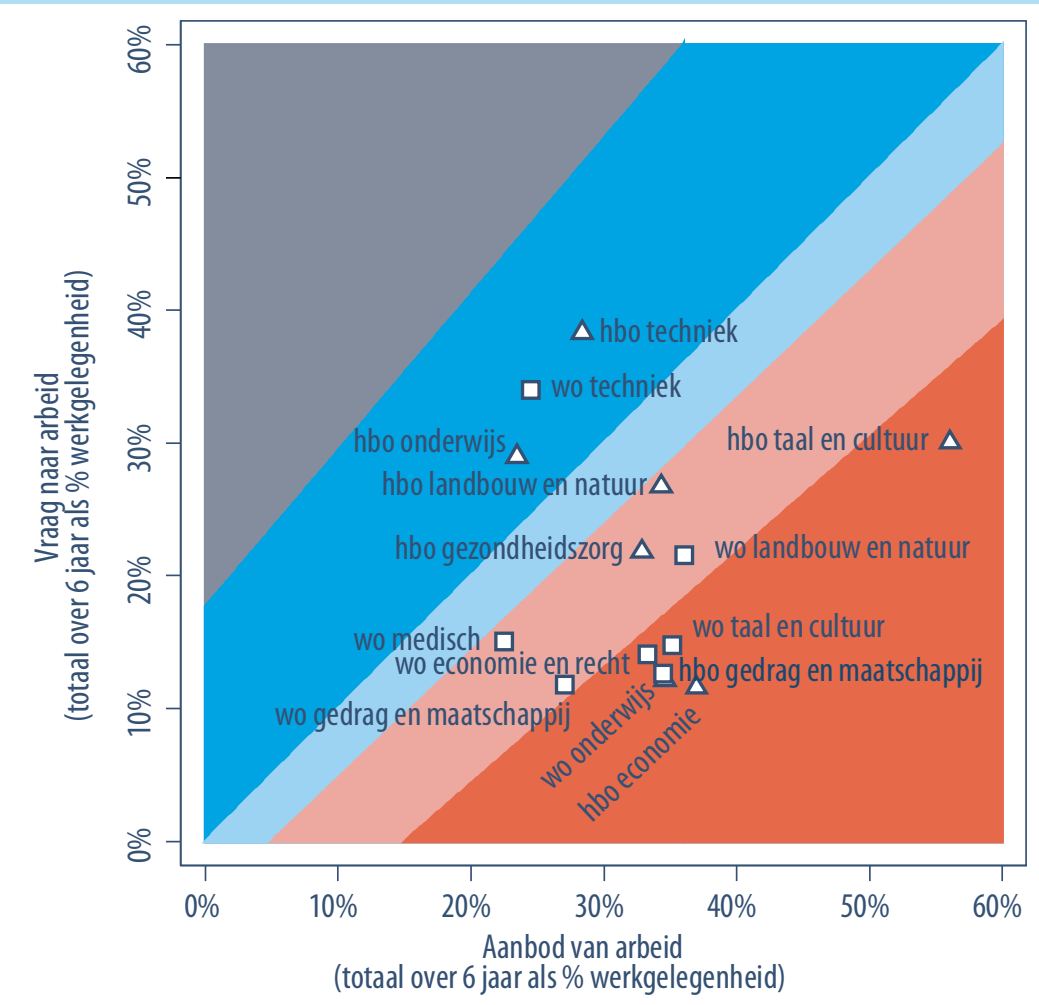

\begin{tabular}{|cl|}
\hline & Perspectief zeer goed \\
& Perspectief goed \\
& Perspectief redelijk \\
& Perspectief matig \\
& Perspectief slecht \\
& hbo \\
\hline & wo \\
\hline
\end{tabular}




\section{Figuur 4}

Arbeidsmarktperspectieven (ITA) versus specialisatie naar opleidingscategorie, Rijk van Nijmegen

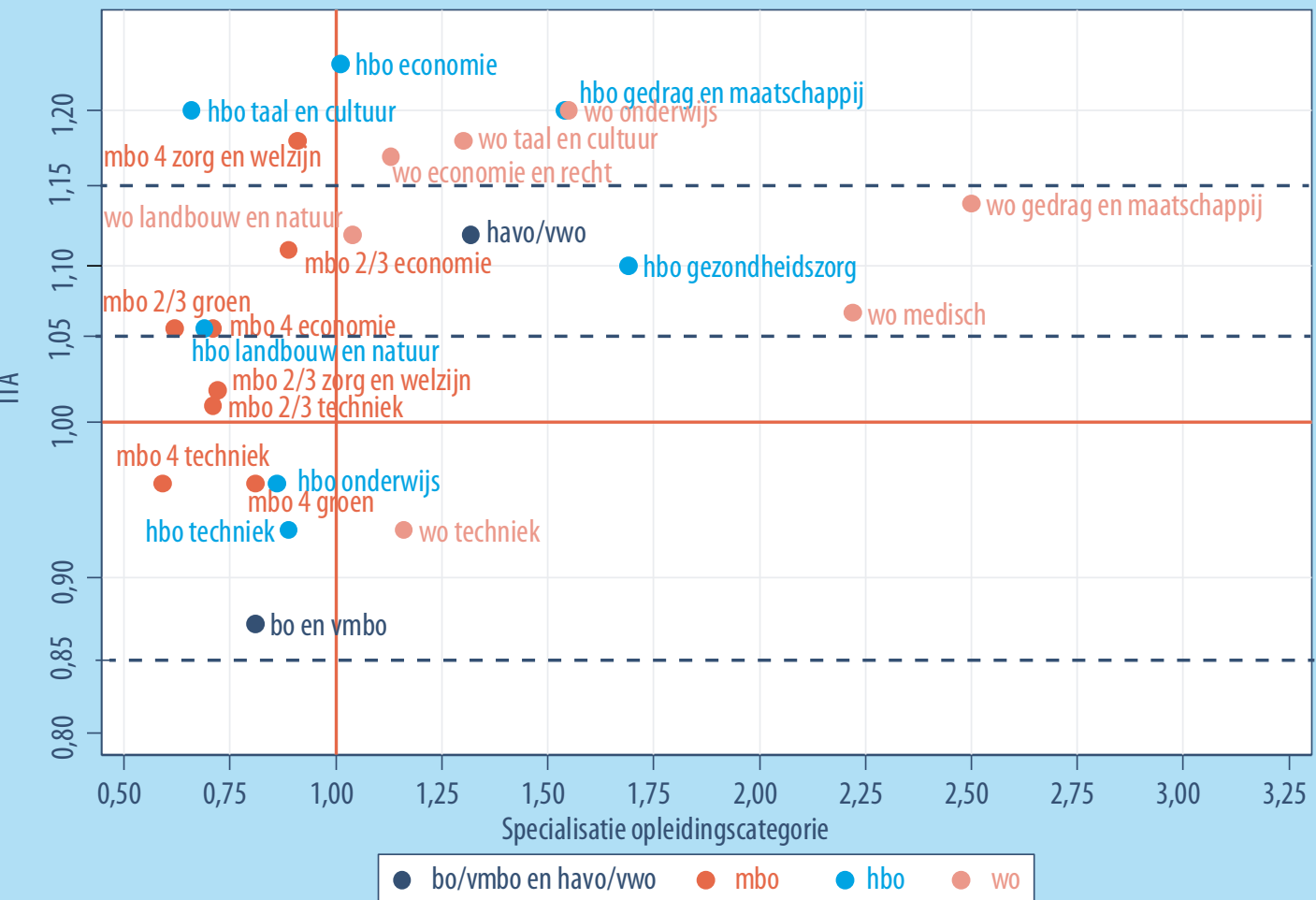




\section{Colofon}

( ) Researchcentrum voor Onderwijs en Arbeidsmarkt Niets uit deze uitgave mag op enige manier worden verveelvoudigd zonder voorafgaande schriftelijke toestemming van de directeur van het ROA.

Researchcentrum voor Onderwijs en Arbeidsmarkt

Maastricht University

School of Business and Economics

secretary-roa-sbe@maastrichtuniversity.nl

www.roa.n

\section{Vormgeving}

ROA secretariaat, Maastricht

juni 2018 